\title{
Resisting Enculturation in Canadian Elementary Schools: Culturally Contested Issues of Latin American Parents
}

\author{
Judith K. Bernhard
}

Ryerson University

Marlinda Freire

University of Toronto

\section{Veronica Pacini}

Western University

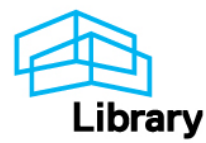




\title{
Resisting Enculturation in Canadian Elementary Schools: Culturally Contested Issues of Latin American Parents
}

\author{
Judith Bernhard, Marlinda Freire, Veronica Pacini.
}

1998

Please address any correspondence regarding the content of this article to the author:

Judith Bernhard, Ph.D.

School of Early Childhood Education

Ryerson Polytechnic University

350 Victoria St.,

Toronto, Ontario

We went to school to shed bad manners: rowdy manners, nigger manners, Creole manners - all the same thing... The vibrant spirit of learning and our Creole beings seemed to be in insurmountable contradiction. The teacher had not only us to contend with but also the entire country. He saw himself embarked upon as a mission of civilization, something like those missionaries who bury themselves in savage lands. Day after day, from one watering hole to another, without an ounce of pleasure, these finders of lost souls pressed on. The effort demanded was colossal, beyond mere brute strength. Since he had to slog through the mire every second he spent with us, each of his gestures, commands, and murmurs was armored with the Universal. The Universal was a buckler, a disinfectant, a religion, a hope.... (Chamoiseau, 1997, p. 97)

As Chamoiseau's (1997) devastating tale of his experiences as a Creole speaker in the Francophone schools of Martinique so powerfully illustrates, subtractivity erases a child's ethnic and cultural identity, and hence can do irreparable damage to his or her self-esteem. In addition, the loss of the home language and culture has deep implications for children and families, not only in terms of lessened employment prospects in the future, but also because home language maintenance is intricately connected with a family's ability to pass on their culture. The subtractive experience that Chamoiseau describes is in many ways similar to that of minority and working class children in Canadian schools.

In Canada as in the US, there is much talk of partnerships with parents, and parent collaboration. Parental involvement is said to promote home-school communication, decrease dropouts and absenteeism, and help build parental strategies for helping children. There are also calls for recognizing diversity and promoting a multicultural society. What is not looked at often is the relations between certain groups of parents and the educational system and how these are 
structured according to mainstream and dominant social relations (Cummins, 1984, 1996; Corson, 1993, 1998; Darder, 1991). The educational system evidences dominant social values and beliefs that organize what is seen as normal and appropriate. When the dominant group defines what cultural capital is, cultural differences become "deficits". The knowledge of working class families is not validated, nor are their views sought (Delgado-Gaitan, 1991, 1993; Laureau, 1989; Valdés, 1996). The families' desire for collaboration is not seen and they are said not to value their children's success. For such families, structural barriers to true collaboration or partnerships are almost insurmountable.

By looking at the experiences of parents, we can see the barriers they encounter in trying to be advocates for their children and how these can be overcome. This study is based on monthly meetings we conducted with Latin American parents in Toronto over an 8 month period. During these meetings, parents discussed their children's education. They developed an awareness of their marginalized position in the system and were able to resist the institutional domination. Empowerment, as a process, created an awareness in the parents that they could control their own fate, and they were able to act accordingly.

Our assumption in organizing and supporting the Latin American Parents Group was that parents' values are worth knowing and that they have a right to have input in the educational decisions regarding their children. Further, by parents learning to assert their interests and collaborate with teachers, we hope eventually to reverse the documented trend for poor academic performance of Canadian Latino children (Brown, 1994; Drever, 1996).

From our transcribed audio tapes, we report on mothers' stories and accounts characterizing their encounters with the official discourses of schooling. Particularly, we show how they challenged labels of deficiency and came to act in resistance to the schools' procedures which ranged from complete lack of acknowledgement to administration gestures which patronized the efforts of the parents.

\section{Demographic Changes in Canada}

Over the past decades, Canada, a nation of approximately 30 million people, has witnessed significant changes in the ethnocultural characteristics of its population. Although the immigration patterns have remained stable for decades, what has altered significantly is the ethnocultural and linguistic diversity of immigrants as well as their choice of residence.

The 1996 Census reveals that 3.2 million Canadians identify themselves as members of a visible minority. Compare this to 1.9 million in 1991 and 1.0 million in 1981 (Statistics Canada Daily, February 17, 1998). Toronto, Canada's largest city, is home to 1.338 million persons who identify themselves as visible minority.

The diversity in the Canadian population is also illustrated in the variety of languages represented. According to Statistics Canada (1993), 32\% of the total population of 27 million report a home language other than English or French. To put our study in context, Canadian figures for those with Spanish as a mother tongue more than doubled from 70,000 in 1981 to 187,000 in 1996 (Statistics Canada Daily, February 17, 1998). 


\section{Group Organization}

This process of group participation and conscientization is in accord with participatory and action research paradigms. We agree with Lather (1986) that the Latino parents' case is not merely a case of data waiting for an objective inquiry but is a case where within a different research approach, we provide interpretations of interpretations.

Over the eight month period, a group of 8-12 parents met on the first Tuesday of the month. They all had at least one child of primary school age. Parents attending the focus groups were contacted through community associations and asked to participate in this series of group sessions. The two hour meetings were held in a neighbourhood community center in Toronto. During the sessions, all conducted in Spanish, refreshments and child care was provided. The role of the facilitator was to introduce each session, initiate the discussion by asking a question, and listening to the group comments. Each session was tape-recorded, transcribed, and coded. The facilitator would summarize the topics discussed on previous sessions and ask the participants whether they wanted to elaborate on those topics or discuss other issues.

\section{Profiles of the Parents}

The Latino mothers who attended the groups were from the following countries: Argentina, Chile, Peru, Uruguay, Venezuela, El Salvador, Nicaragua, and Mexico. They resided in the Toronto area and had lived in Canada less than 11 years. Some of their children were born in Latin America, but most were born in Canada. The ages of the children attending school varied from 5 to 12 years old. In the home country, the mothers had all completed high school, two had college degrees, and one had been to university. However, none of the mothers was able to continue her profession in Canada; they were working in factories, restaurants and in housekeeping. The participants in this study differed from those in previous studies of Latinos in the US since in the Toronto schools, they were a very small minority.

An examination of parents' responses to their participation within the Latino parents group with a particular focus on the multiple facets of their identity, gender, race, and class, shows how these factors affected their process of empowerment.

\section{Findings}

\section{Context of Parents' Interactions with the Schools.}

In our early meetings mothers gave examples of how schools made them feel uncomfortable and not welcome. The example of Mrs. Romero shows how, although she was eager to find out more information about her child's classroom progress, she had difficulties reaching the teacher:

En el colegio de mi hijo, los padres no entran a la clase. La profesora recibe a los niños en la mañana y entran a la clase. No tengo posibilidades para hablar con la maestra. 
In my son's school, parents can't get into the classroom. The teacher receives the children in the morning and they go to class. I don't have the opportunity to speak with the teacher.

A mi me gustaría saber porqué mi niño está en una clase mixta, pero no sé si yo debería preguntarle a la profesora sin que nazca de ella. No puedo llegar y decir: yo quiero que lo cambien a un grado simple. Ella sabe porqué puso al niño en ese grado. Yo no quisiera que hubiera un roce. Pero a mi me preocupa mucho.

I would like to know why my son is in a mixed-age class, but I don't know if I should ask the teacher without her saying anything. I can't just say: I want you to change him to a single-age class. She knows why she put him in that class. I wouldn't want to have problems with her. But, it worries me a lot.

Mrs. Romero's fear of discussing her son's placement with the teacher reflects the recognition of her position in an inequitable power relation that prevents her from speaking as an equal partner. The teacher's actions did not demonstrate that this parent's views were valued or that she should have a say in decision-making.

A further barrier to parental participation was the "in group" of parents who took it upon themselves to represent parents' interests. Mrs. Gonzales:

Hay un grupo de padres que están siempre en la escuela y ese grupo es el que mueve la escuela.

There is a group of parents who are always in the school and this is the group that leads the school.

El mayor porcentaje de los que participan en las escuelas y en actividades no son Latinos. Cuando yo voy a la escuela los padres que siempre están metidos en la clase me hacen sentir como que ellos son superiores.

Latinos are not the higher percentage of the parents who participate at schools and in activities. When I go to the school, the parents who are always involved in school activities make me feel like they are superior compared to myself.

The school's calls for parent partnerships ring hollow in view of their silence on the power inequities between parents and between parents and teachers. The parents did not have opportunities to find out what was happening with their children or to become meaningfully involved. 
Given the barriers and sense of isolation they faced, the parents resigned themselves to hoping that the teachers, as authority figures, would know what they were doing. In Rita's words:

Yo a veces noto como que mi niña se va quedando de lado en la escuela. Ella nunca tiene tareas para la casa porque el profesor dice que ella no tiene problemas. El me dijo que no tengo que preocuparme. Pienso que él debe saber porque lo dice.

Sometimes I notice that my daughter is left behind in school. She never has homework because the teacher says that she doesn't have any problems. He told me that I don't have to worry. I think he must knows why he is saying that.

These examples show that we are only beginning to uncover the complexity of the interactions between Latino families and the schools. Where we see lack of parental participation, this is not to be interpreted as lack of interest or motivation on the part of parents. Rather we must understand these actions within the context of problematically unequal parent-teacher relations and implicit messages that result in parents being marginalized.

As our group progressed, the parents began to interact with the schools, to assert themselves, and to know their views would be heard. Mrs. Blanco:

Mi hija estaba entusiasmada por ir a un viaje de tres dias entonces yo le pagué el pasaje. Pero un día me dijo que no queria ir porque se iva a sentir muy sola y nunca habia estado fuera de la casa. El director me dijo que la niña tenía que ir porque yo ya había pagado. Yo le dije discúlpeme pero yo no puedo hacer eso, si mi hija no se siente bien, yo no puedo mandarla. Me mantuve firme y me devolvieron el dinero. El grupo le da a uno como más seguridad en que uno puede hacer lo que siente correcto con sus hijos.

My daughter was enthusiastic about taking a trip for three days, so I paid for the ticket. But then she told me she didn’t want to go because she was going to feel alone and she had never been away from home. The principal told me that my daughter still had to go because I had already paid. So I said to him: excuse me, but I can’t do that. If my daughter doesn't feel good, I cannot send her. I was firm and they gave me the money back. The group gives one more security in the way that we can do what we think is right with our children.

This mother now knows she has the last say and that her views have validity. She understands how the system works and that her input can be heard. Let's look at each facet of the marginalization and the process of empowerment. 


\section{Understanding the Facets of Marginalization}

\section{a) Gender}

Gender represented an important factor for the mothers in their relation with schools. They encountered more resistance when they approached the teacher by themselves than when a male figure was present in their meeting with school personnel.

He tenido oportunidades en que he ido al school con mi marido para hablar con el maestro y noté que había una cierta cosa, como más consideración porque estaba él alli. Una vez a él le preguntaron por su opinión y que le parecía, y hasta le dieron opciones.

I've had instances in which I've gone to the school with my husband to speak with the teacher and I noticed something, like there was more consideration because he was there. Once, teachers asked him for his opinion, asked him what he thought about the situation, and they gave him more options.

Cuando vamos a las reuniones con mi esposo, la profesora siempre tiende a dirigirse a él en vez de a los dos.

When I go to meetings with my husband, the teacher always tends to speak toward him rather than to both of us.

As these examples show, the mothers came to have a better understanding of the effect of gender on their marginalization.

b) $\underline{\text { Race }}$

The parents in our groups were of different skin colors and racial backgrounds. Nonetheless, many of them had a sense of the Latin American people as being a race. As Mrs. Cabreara said:

La escuela donde va mi niño tiene una población

fundamentalmente portuguesa, hispana, e italiana. El problema es que la mayoría de los profesores y autoridades son gente que no tienen una descendencia latina. Entonces siempre hay favoritismo por otras razas.

My son’s school has a mainly Portuguese, Hispanic, and Italian population. The problem is that the majority of teachers and authorities are people who don't have a Latino background. So there is always favouritism for other races. 
This mother uses the term "raza" to mean an ethnocultural background, not simply in reference to color. The mothers of darker color referred to the additional racism of skin color.

Tuve que enfrentar a la maestra porque estaba siendo injusta con mi niña y yo dije: yo soy nadie en esta escuela, porque en realidad era la segunda Latina en la escuela. Nadie me conocía. Pero yo la enfrenté aunque fue bastante difícil para mí, por mi color, mi lengua, mi nacionalidad, mi cultura.

I had to confront the teacher because she was being unfair to my daughter and I said: I am no one in this school, because in fact I was only the second Latina in the school. Nobody knew me. But I still confronted her, even though it was fairly difficult for me, because of my colour, my language, my nationality and my culture.

The mothers elaborated on their understanding of how their race was an important factor in their marginalization.

Yo pienso que nosotras tenemos que tener bien claro nuestra posición en esta sociedad. Nosotros tenemos muchas desventajas sobre cualquier otro grupo en Canada, especialmente por el color de nuestra piel y nuestro idioma por otro lado. $Y$ yo pienso que nuestros niños también tienen esas desventajas en la escuela.

I think that we have to have clear what our position in this society is. We have many disadvantages compared to any other group in Canada, especially in terms of our skin colour and our language. I think that our children also have these disadvantages in school.

Our Latin American mothers had a complex definition of "Latino race", involving descent, nationality, culture and language. They feel that Latinos are a people. In line with that definition, they feel racial discrimination and label it as such. Color discrimination is experienced as a further dimension of the problem.

\section{c) $\underline{\text { Class }}$}

Another dimension of the mothers' marginalization is related to their socio-economic position. As Mrs. Perez notes, the inability to buy name- brand labeled clothing is a disadvantage that her daughter is suffering:

Mi niña está siempre preocupada por la ropa que lleva a la escuela, la marca de las zapatillas y ella vive pendiente de eso. Los niños tienen enormes presiones en cuanto a marcas. Pero yo en realidad no se las puedo comprar. Yo trato de darles valores a mis hijos de que no importa la marca de la ropa y cuanto cueste. Yo 
pensaría que eso sería tarea de los educadores, pero no es así. Nosotros los padres luchamos por darles esos valores y que los niños entiendan que nosotros no podemos gastar todo ese dinero, pero eso no se valoriza en la escuela.

My daughter is always worried about the clothes she wears to school, her running shoe brand... Children have great pressures with regard to brand names. I try to give values to my children saying that it is not important to have brand name clothes. I would think that this is teachers' job, but it isn't. We, parents, fight for giving children those values and to make children understand that we cannot spend that much money, but these things are not valued at school.

This mother also has an awareness of the disadvantage of the Latino community:

Lo que sucede también es que nosotros somos una comunidad que tiene que trabajar muy duro todavía. Otras comunidades están económicamente mucho mejor que la nuestra. También están políticamente más unidas. Entonces esas comunidades evidentemente que participan y tienen poder y fuerza.

What happens is that we are a community which still has to work very hard. Other communities are economically better off than us. They are also politically unified. So, those communities evidently participate and have power and are strong.

The school Mrs. Perez's children attend is in a poor, immigrant neighborhood. In this case, cultural capital involves wearing the right clothes. The school is unconsciously furthering the dominant values of consumerism. The parents' values which condemn fancy and ostentatious clothing deserve to be recognized. So in this case, where mothers believe that a focus on brand name clothing is wrong, the school should make efforts to recognize these values (have media courses, role models). The school is a contested site but as minority parent groups come to assert themselves, it could assume the role of supporting parents by providing the tools to resist enculturation.

\section{Empowerment: Mothers’ Responses to their Participation within the Group}

In the process of coming together, the parents validated themselves and the so-called deficiencies seemed to melt away. They found ways to overcome the barriers and penetrate the school walls:

Dije que voy a empezar a meterme y a molestar tanto a las maestras, que me van a escuchar. Ahora estoy allí. $Y$ con todos los padres que somos si nos empezamos a meter y a estar allí $y$ obligar a que escuchen, nos van a dejar entrar. La otra vez la maestra me pidió que venga a ayudar a leer a los niños. 
I decided I'm going to start to get in the school and to bother teachers so much that they are going to listen to me. Now, I am there. And with all of us parents together, if we all start to get in there and make them listen to us, they will let us in. The other day, the teacher asked me to go to school to help children with their reading.

The effects of the parents' support group were two-fold. Not only were parents empowered enough to take a more active role in making their views known to the teachers, but by sharing with other women, they became able to affirm their differences rather than accept the label of deficit in parental values or motivation.

Getting Schools and Teachers to Respond to the Parents.

The mothers began to take action and make their voices heard as they accomplished a variety of goals in relation to schools. For example, one mother talked about how she was empowered to continue the discussion with the school as she encountered resistance with regard to her requests to enroll her child in French Immersion:

Yo le dije a la profesora que quería que mi hijo vaya al programa de francés y ella dijo que no porque el niño no hablaba bien el inglés. Pero yo le dije a la profesora: cuál es la diferencia si el inglés no es la primer lengua para el niño? El francés también va a ser una nueva lengua para él. No entiendo cual va a ser el gran problema... Entonces la profesora hizo una reunión especial en la cual estaban el principal, alguien del board, una sicóloga, y un social worker. Cuando llegué a la reunión, yo tenía tanto miedo pero igual les dije a ellos lo que yo quería y finalmente ellos dijeron okay.

I told the teacher that I wanted my child to go to the French program, and she said no because my son didn't know English well enough. But I told the teacher: What's the difference if English is not my son's first language? French is also going to be a new language for him. I don't understand what the problem is going to be ... So the teacher made a special meeting in which the principal, someone from the board, a psychologist, and a social worker were present. When I got to the meeting, I was so scared, but I still told them what I wanted, and finally they said okay.

There were other ways in which parents made the school take appropriate action.

Yo tuve un problema así con Juanito: un niño le pegaba, le pegaba y yo le dije a la teacher dos veces. Ella no hizo nada. Le digo llámeme a la mamá del niño, porque no quiero que le vaya a pasar nada a mi hijo. Inmediatamente ella dijo ya le hablo al niño. Y el 
niño se calmó. Llamó a la mamá y todo. Pero si uno no se pone, olvidate, te pasan y te vuelven a pasar y te vuelven a pasar.

I had a problem with Juanito: A child was hitting him so I told the teacher twice. She didn't do anything. I told her: Call the child's mother because I don't want anything to happen to my child. And the child calmed down. She called the mother and everything. But if one doesn't get firm, forget it, they step all over you, and they keep on stepping on you.

Una vez la secretaria me llamó para que fuera a buscar al niño porque se había pintado la cara y estaba distrayendo a los otros niños en la clase. Entonces me dijo que el niño estaba incontrolable y que lo fuera a buscar ya mismo. Me dijo que ya no sabían más que hacer. Yo le dije que no iba a ir a buscarlo. No creía que fuera para tanto.

Once, the secretary of the school called me to pick up my son because he had painted his face and he was distracting the other children in the classroom. So she said that my son was uncontrolable and I had to pick him up immediately. I told her that I wasn’t going to go. I didn’t think it was so terrible.

This second mother understood her son was being judged according to mainstream standards and his behavior was being labeled as deficient. It would be a mistake to call this mother unconcerned and overly permissive. She simply had a different view of the kind of play children might be properly involved in. She did not simply accept the school's assessment of the situation. Rather, she knew her views were valid and that she could have the last word.

Being able to support others in understanding their marginalization in the educational system was an additional outcome of the group meetings. Mrs. Rodriguez:

Esta reunión me ha servido para ayudar a otras amigas que tienen problemas con sus hijos en la escuela. Les digo: mira puedes ir aquí, o hacer esto, o hacer el otro. Dándoles como más fuerza. Esto me ha servido para comunicarle a otros porque en realidad hay gente que no sabe como enfrentarlo.

This group has served as a way for me to help friends who have problems with their children at schools. I can tell them: Look you can come here, or do this, or do that. It helps me to give them [my friends] strength. This has served me to communicate to others [parents], because there are people who don’t know how to confront this. 


\section{Limitations}

There are reasons to be cautious about the positive findings of this study. In spite of the parents' empowerment, systemic barriers continue to exist. Our intention in this paper was not to make claims about Latino parents as a homogenous group; indeed there existed people within the group who disagreed with points raised by other parents. For instance, while gender emerged as a major issue, many of the mothers did not feel a difference in approaching school personnel with their husbands.

\section{Discussion}

These finding show the parents' experiences as they deal with institutional impediments. They clearly show that there is no basic deficiency of motivation or interest. Although mothers back off and become passive in certain circumstances, they truly care and want their children to do well.

Their so-called non-participation amounts in fact to an unwillingness to participate according to institutional norms and as desired by the teachers. Their alleged passivity is an outcome of the dominance of present school structures which place some parents outside the decision making system and devalue their assets and skills.

Yet the school system can be influenced. Especially in the present times, schools are being called to accountability. Thus when parents come together outside the school and exert themselves upon the school, they can bring about changes. In the process of coming together to discuss their children's education, the so-called objective deficiencies are demystified. Collectively, these parents began to understand the position they were in, relative to the system. They saw beyond their individual experiences, began supporting one another, began to speak up, and took steps toward customizing their children's programs. Lareau (1989) has observed the power of the upper middle class to customize programs for their children. We propose these mothers were beginning to learn how to accomplish such a goal. This, we submit, is an example of what Freire (1972) called the process of conscientization.

We have argued elsewhere that guidelines for schooling are reflected in official documents which place teachers and administrators in the role of experts who listen to the input of parents but are not on an equal footing of power with them (Bernhard et al., 1998; Bernhard et al., in press). Parent groups organized outside the school can implicitly challenge an expert model and in effect work toward a collaborative approach to education.

Although it may be unrealistic to expect the schools to provide a multiplicity of different programs aimed at enculturation of every minority group represented, it may be more useful to support a structural arrangement which encourages minority groups to coalesce and support each other, eventually merging with more powerful groups to affect the agenda of schooling. Schools should actively support the development of such groups. This has proved to be relatively inexpensive and a very effective way of supporting children and families. 


\section{References}

Bernhard, J. K., Lefebvre, M. L., Murphy Kilbride, K., Chud, G., \& Lange. (1998). Troubled relationships in early childhood education: Parents-teacher interactions in ethnoculturally diverse child care settings. Early Education \& Development, 9 (1), 5-28.

Bernhard, J. K., Gonzalez-Mena, J., Chang, H. N., O’Loughlin, M., Eggers-Piérola, C., Roberts Fiati, G., \& Corson, P. (In press). Recognizing the centrality of cultural diversity and racial equity: beginning a discussion and critical reflection on "developmentally appropriate practice". Canadian Journal of Research in Early Childhood Education.

Brown, R. S. (1994). A follow--up the Grade 9 Cohort of 1987 secondary students survey participants. Toronto: Toronto Board of Education.

Chamoiseau, P. (1997). School days. London: University of Nebraska Press.

Cummins, J. (1984). Bilinguism and special education: Issues in assessment and pedagogy.

Clevedon, England: Multilingual Matters.

Cummins, J. (1996). Negotiating identities: Education for empowerment in a diverse society. Ontario, CA: CABE.

Corson, D. (1993). Language, minority education and gender: Linking social justice and power. Toronto: OISE Press.

Corson, D. (1998). Changing education for diversity. Philadelphia, PA: Open University Press.

Darder, A. (1991). Culture and power in the classroom: A critical foundation for bicultural education. Toronto: OISE Press.

Delgado-Gaitan, C. (1991). Involving parents in the schools: A process of empowerment. American Journal of Education, 100, 20-46.

Delgado-Gaitan, C. (1993). Research and policy in reconceptualizing family-school relationships. In P. Phelan, \& A. Locke Davidson (Eds.), Renegotiating cultural diversity in American schools (pp. 139-158). New York: Teachers College Press.

Drever, N. (1996). Frustrated learners: An ethnographic study of Spanish-speaking students at an inner-city high school in Toronto. MA Thesis: University of Toronto.

Freire, P. (1972). Pedagogy of the oppressed. New York, NY: Continium.

Lareau, A. (1989). Home advantage: Social class and parental intervention in elementary education. New York: The Falmer Press.

Lather, P. (1986). Research as praxis. Harvard Educational Review, 56 (3), 257-277. 
Statistics Canada. (1993). Mother tongue: The nation. Ottawa: Supply/Services Canada.

Statistics Canada Daily. (1998). 1996 Census: Ethnic origin, visible minorities, Feb. 17. Valdés, G. (1996). Con respeto: Bridging the distances between culturally diverse families and schools. NY: Teachers College Press. 